\title{
Minsky on "Big Government"
}

\section{DANIEL DE SANTANA VASCONCELOS*}

This paper objective is to assess, in light of the main works of Minsky, his view and analysis of what he called the "Big Government" as that huge institution which, in parallels with the "Big Bank" was capable of ensuring stability in the capitalist system and regulate its inherently unstable financial system in mid-20 ${ }^{\text {th }}$ century. In this work, we analyze how Minsky proposes an active role for the government in a complex economic system flawed by financial instability.

Keywords: Government; deficit; fiscal policy; financial instability hypothesis; unemployment; employer of last resort.

JEL Classification: E02; E12; E62; H63.

\begin{abstract}
Only an economics that is critical of capitalism can be a guide to successful policy for capitalism. [...] There is no simple answer to the problems of our capitalism; there is no solution that can be transformed into a catchy phrase and carried on banners. (Hyman Minsky, "Stabilizing an Unstable Economy", pp. 369-370)
\end{abstract}

\section{INTRODUCTION}

Some economists, like some great artists throughout history, seem fated to be discovered (or rediscovered) only when, after his/her death, the world realizes the potential and importance of their work - be it an artistic one, as in the case of the latter, or a theoretical original contribution, as in the case of the former. This seems

\footnotetext{
"Instituto de Economic da UFRJ e InmetroMail to dsvasconcelos@inmetro.gov.br or danielsvas@gmail. com. The views expressed in this article are those of the author and are not reflective of point of views or policies of the Inmetro or UFRJ. A previous draft of this paper was presented at the $11^{\text {th }}$ PostKeynesian Conference, in September, 2012, Kansas City, MO. Submitted: 16/October/2012; Approved: 13/March/2013.
} 
to be the case with the North American economist Hyman P. Minsky (1919-1996) and his monumental work on economic issues. ${ }^{1}$ Minsky, affiliated with the PostKeynesian branch of heterodox economics, worked hardly advancing theoretical points left open by Keynes, but besides it, wrote about microeconomic theory, macroeconomics, banking and public sector economics with the same insightful and fruitful approach. The bulk of his work was dedicated to analyzing financial crises, which rendered his original contributions on financial instability and economic cycles, but he was also one of the first economists to make a theoretical defense of policies of the kind of "employer of last resort" ones (Toporowski, 2006; Erturk, 2006; Papadimitriou \& Wray, 2008; Wray, 2011:1). Yet Minsky was left outside of the economic debate that has dominated the theoretical economic mainstream since the 1970s, because of his affiliation with the heterodox economics school. Besides this, he has always been labeled as a pessimist by his thesis about the intrinsic weakness of the capitalist system, derived from the risk behavior of its financial branch.

Based on a theoretical critique of mainstream economics and powerfully defending an effective and active role for government action on the economy, the Minskyan literature, until recently a matter of interest only to a limited audience of scholars, ultimately has been remembered and discussed with renewed interest in the aftermath of the 2007-2008 Financial Crisis. The media, as some academic circles, released that the first new century great crisis brought the world economy to a "Minsky moment" (Whalen, 2007; Lahart, 2007; Cassidy, 2008; Wray, 2011:2). Putting aside this newspaper style of reducing scientific ideas and theoretical issues to some kind of catchphrase, we are faced with the fact that the Minsky contributions nowadays - and always, in fact - has been a very important answer to questions that this crises has raised, in particular in terms of his major theoretical contribution: the Financial Instability Hypothesis. This theoretical framework constitutes a very accurate description of the mechanism of our crisis prone capitalism. This is an original Minsky contribution, built carefully over an extensive research life that spans nearly forty years of a rich and fruitful academic production. Minsky's extensive list of papers and other works resulted in his three known books, which condensate his lead contributions (Minsky, 1975, 1982 e 1986). Besides this, however, his complete work is currently available in digital archives at Levy Economics Institute of Bard College, ${ }^{2}$ and a growing number of heterodox economists is actually making some important contributions, stemming from Minsky's works. ${ }^{3}$

In fact, with the Financial Instability Hypothesis, Minsky has made a point in

\footnotetext{
${ }^{1}$ It is worth noting that the same thing could be said about J. Schumpeter, who was the first thesis supervisor of Minsky doctoral studies. Minsky did not complete the work under Schumpeter's guidance, because Schumpeter died in the middle of writing the dissertation, which was completed under the supervising of W. Leontief.

${ }^{2}$ See http://www.bard.edu/library/archive/minsky/.

${ }^{3}$ See Papadimitriou and Wray (2010), for a rich collection of papers rooted in Minsky's contributions.
} 
heterodox economic theory, but his works have another important issues to be addressed. In this respect, if, by one side, there is great interest in his discussion on financial instability, on the other hand it seems that there is less or no emphasis on his analysis of the Government role as an economic institution with the essential capability of sustaining full employment and leading systemic stability policy. In this spirit, this paper objective is to assess, in light of the three main works of Minsky and part of his other intellectual production, his view and analysis of what he called the "Big Government", as that huge institution emerged from the Roosevelt years of recovering policies, after the 1929-1933 crisis, which, in parallels with the "Big Bank" (Federal Reserve's role as lender of last resort) was capable of ensuring stability in the capitalist system and regulate its inherently unstable financial system, at least until recently.

Departing from Minsky contributions, we present here a discussion of his view about the Government role in a capitalist economic system which is flawed by financial instability. The first part of the paper discusses Minsky's theoretical reasoning against mainstream economics. There is also an abridged view of the Financial Instability Hypothesis, in such way that the importance of this concept is not ignored in all that follows. The second part discusses the concepts, role and implications of the emergence of Big Government in the aftermath of the 1929-1933 crisis in Minsky analysis. The third part follows from the second, in instance that policy implications of Big Government in pursuit of economic stability is discussed there. The conclusion is the fourth and final part of the paper.

\section{THE THEORETICAL CRITICISM OF THE ORTHODOXY}

One cannot advance in Minsky theoretical works about his perspective on the active role of Government in stabilizing the economy if not departing from the recognition that his analysis starts with an insightful and powerful critique of mainstream economic theory. According to Minsky, a theory which abstracts the existence of what characterizes our economic system is unable to provide political solutions to real economic problems, like economic depression. To him, our system is fully absent in economic mainstream models: there is no place there to a capitalist economy with a complex financial structure, where the preferred organizational form is the big corporation, a system which is subject to severe fluctuations and cycle reversals, and in which the full employment is achieved only very rarely (if it can be achieved at all, actually) like by accident. ${ }^{4}$ To Minsky,

\footnotetext{
${ }^{4}$ Minsky (1975 and 1994:1), Keynes (1973). Minsky, in an handwritten draft (1994:1), subtly distances himself from the Post-Keynesian concept of monetary economy of production, calling it an "euphemism". In another work (Minsky, 1980), he analyses the "coherence of a market economy" as that kind of economic system treated in terms of the Post-Keynesian theoretical approach, without using this terminology. Toward a good presentation of this concept in rigorous Post-Keynesian terms, see Cardim de Carvalho (1992).
} 
The conclusions based on the models derived from standard theoretical economics cannot be applied to the formulation of policy for our type of economy. Established economic theory [...] can demonstrate that an abstractly defined exchange mechanism will lead to a coherent, if not optimum, result. However, this mathematical result is proven for models that abstract from corporate boardrooms of Wall Street. The model does not deal with time, money, uncertainty, financing of ownership of capital assets, and investment. (Minsky, 2008 [1986], p. 4)

A theoretical approach that is unable to explain how the real economy works, cannot, in Minsky reasoning, be able to propose solutions to their inherent problems, because:

[...] for an economic theory to be relevant what happens in the world must be a possible event in the theory. On that score alone, standard economic theory is a failure; the instability so evident in our system cannot happen if the core of standard theory is to be believed. (Minsky, 2008 [1986], p. 323)

This shows that, to Minsky, only a theory which is able to replace what he called the economic paradigm of the village fair by the paradigm of Wall Street can do economic policy and propose solutions to our economic troubles. The paradigm of village fair, as seems the world described so poorly by the orthodox theory, must be replaced by the realistic paradigm of Wall Street, which to him represents with more adherences to the reality of the world where we live in, and corresponds, as a figure, to the kind of problems that the Keynesian theory seeks to address. Minsky argues that only a theory that seeks a realistic understanding of the complexities of our economic relations and which can explain the origin of the kind of crises that mark the system economic cycles can do this job. A vision based on the notion that economies are like natural systems, as claimed by the orthodox school, ignores, moreover, the importance that institutions acquire in the configuration of this system. Only a vision that combines a realistic truly perception of the economic system with its institutional dimension can accept that the policy has an active role in setting and maintaining system stability:

Economic systems are not natural systems. An economy is a social organization created either through legislation or by an evolutionary process of intervention and innovation. Policy can change both the details and the overall character of the economy, and the shaping of economic policy involves both a definition of goals and an awareness that actual economic processes depend on economic and social institutions. (Minsky, 2008 [1986], p. 7)

It follows that: 
[e]conomic policy must be concerned with the design of institutions as well as operations within a set of institutions. [...] We cannot, in a dynamic world, expect to resolve the problems of institutional organization for all time. On the other hand, we cannot always be engaged in radically changing institutions. Once an institutional arrangement embodies the day's best perception of the processes and goals, it should be allowed a run of time in which details are permitted to evolve and policy is restricted to operations within the institutional structure. (Minsky, 2008 [1986], pp. 7-8)

The Government, therefore, emerges from the Minskyan perspective in an active role, performing as a crucial agent in the economic system. This perception is a direct response to the new understanding of how capitalist economy works out, which changes dramatically with the emergence of Keynes's works, in particular, the General Theory (Keynes, 1973; Minsky, 1975), on one hand, and the understanding, brought about by Keynes's theoretical approach, that "our economic destiny is controllable"(Minsky, 1986, p. 8, italics added). This can be done by aware management of the economy, especially of the macroeconomic policy, in particular, which is driven by the two key economic agents in the Minskyan analysis: the Government (which, in his writings, is labeled the "Big Government") and the Central Bank (or the "Big Bank"). ${ }^{5}$

\section{A parenthesis: Financial Instability Hypothesis}

By its insightful and fruitful theoretical reasons, and so much more frequently, Minsky work in what he termed Financial Instability Hypothesis (FIH, hereafter) constitutes the great subject of discussion among those who focus on his theoretical contributions. Although being not the main object of present paper, it is worth making a brief description of FIH, since this theoretical element is the fundamental axis of all the Minskyan approach (Lawrence, 2006; Papadimitriou \& Wray, 2010; Ferri, 2010). What FIH shows is that in a capitalist economy with a sophisticated and complex financial system - the Minsky's so-called Wall Street paradigm (Minsky, 1982, p. 61), which constitutes the current paradigm of economic system, instead of the village fair paradigm, in which the orthodox approach is based upon - there is an empirical regularity of alternating periods of stability and turbulent

\footnotetext{
${ }^{5}$ In this sense, Minsky follows very closely the idea advocated by Keynes himself, from his General Theory, that the macroeconomics is like the scientific management and conscious reconfiguration of the economic system targeting economic stability and full employment. In this regard, as noted by Cardim de Carvalho (1997, p. 41), "The possibility of planning, in the sense of preparing intervention plans to compensate for the eventual lack of private investments, was enhanced, in Keynes's view, by the fact that the government is not just another guess-maker as to future trends but is, to a large extent, a builder of the future, through its power to mobilize resources and to influence aggregate demand" (italics added). See, with the same approach, Cardim de Carvalho (2008).
} 
waves (recessions and crises), which is endogenous to this system. This implies that there is a structural weakness in the capitalist economy, which is systemically endogenous, or, in other words: instability is an endogenous characteristic of this system as it results from its normal dynamics. It is not an external shock that drives the economy to the brink of depression: in fact, depressions are dynamically and inherently produced by the same agents and risk behavior which sustains capitalist normal functioning.

This crisis-prone capitalist economy normal functioning results from the dynamics of economic agents, in terms of their liability structures and risk behavior (Minsky, 1982). In a modern capitalist economy, agents have portfolios of financial assets (capital goods, bonds, debts, commercial papers), which they contract in a time basis. There is always a chance of a time mismatch between taking out a loan and its effective discharge, for example. In any period of time, there are debts maturing and new debt being contracted based on expected income of future cash flows in order to pay this debt. The agents pay now for the debts from the past, and manage to get new resources by contracting new debts to be fulfilled in the future. The agents have different risk preferences, so their liability structures reflect their risk behavior with respect to their debt structures. Besides this, the predominant agents' behavior changes according to the economic cycle in terms of risk aversion, in respect to their real capability to perform these debts in time of debt's maturity (Minsky, 2008 [1986]).

Minsky describes carefully what the agents' risk behavior is and how it results in this endogenous characteristic of nowadays crisis-prone capitalism. In the immediate aftermath of an economic debacle, as in the 1930s, agents are more cautious, and act as hedge agents: its future revenues are sufficient to pay its debts and interest in the contracted debts' term. But there are another kind of agents, whose behavior, called speculative by Minsky, permits the payment of the portion of the interest, but the debt's principal should be renegotiated periodically as well as the speculators try to forecast future changes in the economic scenario that will allow the full payment of the debts. The proportion of speculative agents in the economy grows as the perception of risk is obliterated by the vision of gain opportunities by leveraging positions in assets through debts. And finally, there are agents called Ponzi (in reference to Charles Ponzi), who cannot perform the principal payments in a reasonable time horizon, nor even the interest's payments, in a way that drives Ponzi agents to capitalize their debts in an unforeseen deadlines basis (the debt is rolled over and over indefinitely, so the principal is continually compounding, towards an explosive behavior). Alongside the economic cycle, there is a shift the relative weight that these agents have on the economy: at each moment in time, one of them is the prevailing group in the economic landscape.

With the detachment of the "memory" of the crisis, the agents, while gaining greater confidence in the favorable swing of the economy, acquire a risk behavior more prone to risk than to insurance (what is to say: they change their risk behavior from hedging to speculative bets, and at the brink of the safety, they becoming to be, ultimately, Ponzi gamers). The proportion of speculative and Ponzi agents 
increases as the economic cycle develops steadily. At this point, the economy is becoming increasingly risky, in the sense that even a very small shock (be it an endogenous, as a regulatory change, or an exogenous one, such as an external event that affects the economic environment) will trigger a process of debt deflation. ${ }^{6}$ The shock affects the most exposed agents first, but is propagated through the system as a whole, as the liability structures are linked together (one's agent balance sheet debt is an asset in another agent's balance sheet). That's to say that the very stability of the system provides the psychological environment of greater quest for profits through increased exposure to risk, which leads the economy to become weaker (in safety terms) the more it extends the stable phase of the cycle. The liability structures of balance sheets inflate, and eventually fall apart into their own weaknesses. In this sense, Minsky states his most cited aphorism: that "Stability - or tranquility - in a world with a cyclical past and capitalist financial institution is destabilizing" (Minsky, 1982, p. 101). The entire system works in order to expand its financial instability as the economic cycle develops from boom to burst. But in doing in this way, Minsky arguments, this crisis-prone trend does not indicate that the economy is something like a random walk. There is a trend in capitalism to maintain a pace of growing that sustains itself and the development of the agents' behavior in a growing manner: as Minsky says, the instability of capitalism is upward:

Stable growth is inconsistent with the manner in which investment is determined in an economy in which debt-financed ownership of capital assets exists, and the extent to which such debt financing can be carried is market determined. It follows that the fundamental instability of a capitalist economy is upward. The tendency to transform doing well into a speculative investment boom is the basic instability in a capitalist economy. (Minsky, 1982, p. 65, italics added)

\section{THE "BIG GOVERNMENT": ITS ECONOMIC ROLE AND ITS SIDE EFFECTS}

Since we understood the big picture from which Minsky work develops - the Financial Instability Hypothesis - we now turn to our particular subject, which is, in this paper, to focus on how he deals with the Government role in a capitalist economy with complex financial system. This is, obviously, a partial and particularized analysis, resulting from a specific focus in a institution that is a fundamental agent in this larger framework perspective proposed by FIH. In this sense, we get a better understanding of the Government role in Minsky approach if we consider

\footnotetext{
${ }^{6}$ Minsky owes to Irving Fisher (Fisher, 1933) his approach to the concept of debt deflation (Minsky, 1994:3).
} 
his broader history analysis of the recent U.S. economy. In a 1994 text prepared for a speech at the Levy Institute, Minsky, in evaluating the $20^{\text {th }}$ century, wrote that:

The experience of the twentieth century provides material supporting the proposition that the big government interventionist capitalism that was developed as a reaction to the great depression was a more successful economic system than the largely laissez-faire capitalism that ruled for the first third of the century. (Minsky, 1994:2, p. 1)

The appraisal of the U.S. economy in the $20^{\text {th }}$ century, in Minsky's view, has three well defined moments, which to him are defined in terms of its economic success or failure, parallel to the Government actions helping (or not) the economy: 1) the first third of a century just ended in 1933 with a huge economic crisis in the capitalist system in the U.S. and Western Europe, is the period in which the Government had a secondary role in the economy (Minsky called this particular form the "small government" model); 2) the post-war period until the middle 1960s, when the Western Europe and North America saw the emergence of the Big Government institution, included in this period a "golden age" of the U.S. capitalism; and, finally, 3) the period after the 1970s, in which the economic performance was better than the first third of the century, but much less satisfactory if compared to the years of the "golden age" from the second term. The latter comprises the third of a century where the Big Government is hurt by a brutal attack, theoretically and politically speaking, addressing some important questions about its effectiveness and economic efficiency, and the orthodoxy states its new economic policy guidelines, based on the now theoretically reformulated axiomatic belief in efficient markets.

The Big Government was lifted up as a remarkable institution of our time starting from the Rooseveltian New Deal, which built and consolidated the particular economic policy institutions that worked in the U.S. economy after the great crisis. After World War II, this new institutional framework were able to provide policy-based material growth by use of effective demand management (with an 'Alvin Hansen' flavoring, Minsky says, attributing the big theoretical influence of Hansen in this policy stance). This is to say: the landmarks of the Big Government were the use of deficit spending as a management instrument of fine adjustment of demand, besides the construction of the welfare state rescue social net, largely anchored in policy transfers (social insurance programs, health care, unemployment insurance and programs for seniors and children). Parallel to this, there was an enforcement of the Government and financial supervision regulating powers, by the means of a strong banking and financial regulation (in the context of the GlassSteagall Act, which divided the U.S. financial sector into watertight compartments, separating commercial banks from investment banks), and the active role of the Federal Reserve System (Fed) as lender of last resort in the financial sphere.

Theoretically speaking, Minsky adopted the Kaleckian perspective of the crucial role of profits as the dynamic instrument of the running of the economy (Kal- 
ecki, 1971; Minsky, 1982). His explanation for this approach toward a periodization of the $20^{\text {th }}$ century into three parts ("absolute failure - success - comparative failure", in his terms; see Minsky 1994:2, p. 3) comes from the analysis of the role played by Government in each of these three main periods, which results from the incorporation, in his analysis, of the idea that the Government has an particularly active function in the economy, which consists in sustaining the profits of the capitalists in times of investment contraction. In doing so, Minsky is accepting Kalecki profits equation (adapted to his approach), as he acknowledges (Minsky, 2008 [1986], chap. 8, e 1995, p. 204). ${ }^{7}$ By this formulation, the level of profits is always determining the level of investment and, hence, of all economic activity.

Take the macroeconomic identity of the product, thus making

$$
C+I+G+(X-M)=W+\Pi+T
$$

The components of the aggregate demand, the left side of $(i)$, are consumption $(C)$, investment $(I)$, Government spending $(G)$ and net exports $(X-M)$, which are, by this identity, equal to the components of national income: wages (W), profits $(\Pi)$ and taxes $(T)$. Rearranging profits for separately, we have:

$$
\Pi=I+(C-W)+(G-T)+(X-M)
$$

It follows that the profits are determined by the sum of private investment to private consumption in excess of the wages, plus the Government's primary deficit and net external sector. Now, assuming that in (ii) the economy's private consumption and external sector are in equilibrium, the remaining profits are determined primarily by deficit spending and investment. For Minsky, therefore, following the Kaleckian proposition, the budget deficit turned into profit for the capitalists. Thus, if and when the investment falls, only the Government as an agent is able to adopt and maintain a countercyclical policy by expanding out the deficit, in order to maintain the profits level at a point capable to reverse downward expectations and, as a result, get the economy at full employment. The first and last third of the $20^{\text {th }}$ century constitute situations of failure of the capitalist system (absolute, in the first third, and relative, in the last one) in the two contexts because in that time the government failed to fulfill and exercise that countercyclical role. The post-war years, therefore, are the clear and sound demonstrations of this thesis:

One source of the difference between the behavior of capitalist economies in the post-World War II period and their behavior in the interwar and earlier periods is the fact that the much greater relative size of government in the postwar period than in the earlier times has made

\footnotetext{
${ }^{7}$ As pointed out by Papadimitriou and Wray (2008, pp. xiv-xv), Minsky FIH was built in the two prices system that he borrowed from Keynes: a price system for the current product and a price system for assets that may be held intertemporaly. This was the result of his careful work on Keynes economics, which resulted in his masterpiece John Maynard Keynes (Minsky, 1975). Later, Minsky incorporated the kaleckian scheme to address some deficiencies of his first approach.
} 
it impossible for profits to collapse as completely now as in the past. In capitalist economies, stabilization is successful to the extent that it stabilizes profits. (Minsky, 1995, p. 11)

In the context of small Government, as used to be the case in the first third of the $20^{\text {th }}$ century in the U.S. economy, a fall in investment leads to a fall in profits, and the resulting decline in the investment level. Such a process can drive to a catastrophic wave, because the decline in investment can start a downward spiral of economic activity. If the government has no ability to stop the process - as occurred in 1929 - the downward spiral can result in a great depression: It happens (to use his famous terminology). A Government capable of meeting the challenge of halting the spiral of depression must necessarily be great. Only the Big Government has the power to do something like a jump starting in the economy, as the "battery" of the economic engine (the investments and profits) is dead (Minsky \& Papadimitriou, 1994, pp. 4-5). ${ }^{8}$ This implies a frontal rupture with all that economic theory that advocates the excellence of market solutions, which implies no one or at least small government shapes:

Because government needs to be big in order to contain thrusts to deep depressions, government and its institutions can do great harm, especially if their actions are based upon 'Pollyana' views of the wonders of markets and a 'true faith' that markets always know best. Policy makers need to adopt a skeptical attitude toward claims that universal truths about economic policy (relevant for all economies at all times) have been derived from economic science. (Minsky, 1995, p. 11)

To Minsky, how great must be the government would be directly linked to the level of private investment that it should be able to cope in the context of a depression. But he suggests, however, something between $20 \%-50 \%$ of GDP as tax revenue in order to allow the government this fire power:

A government that is big enough to contain the depression proneness of capitalism needs a tax system which raises sufficient revenues so that over the run of good and bad years the ratio of government debt to gross domestic product remains in a comfort zone of from 20 to 50 percent of gross domestic product. (Minsky, 1994:2, p. 1)

\footnotetext{
${ }^{8}$ It is needed to say that the government can do this, but it is not the solution to the big problem of healing the financial trauma. More is needed than only fiscal policies. As stated:"If the battery is dead jump starting the car will get the car moving but the battery remains dead. Jump starting as a metaphor for economic policy only makes sense if the economy is analogous to a live battery that has somehow been run down. But if the battery has somehow been shorted then jump starting is ineffective. The financial trauma is equivalent to an assertion that the battery is dead and something more than jump starting is needed" (Minsky \& Papadimitriou, 1994, pp. 4-5).
} 
In the decades of 1910-1930, the then U.S. small government still lacked the theoretical tools appropriate to fight this kind of events (Keynes' General Theory came to light only some years after the crisis, in 1936), nor acquired yet practical experience (without paying attention to some economic dogmas) large enough to play this countercyclical role. On the other hand, at the last third of the century, the Big Government acted less than satisfactory for achieving these stability goals by imposing an orthodox economic agenda which, according to Minsky, operates based on a myopic view about the real issues behind the inflationary surge of the 1970s. As a result, the first third of the $20^{\text {th }}$ century ended with the $1929-1933$ crisis, and the last third with the problems of stagflation, unemployment, and the series of financial crises that erupted in the world, with more insistence in the 1980s.

This division of the $20^{\text {th }}$ century into three parts and this evaluating of how was the Government performance in each of them reinforces the central thesis of this part of Minsky's analysis: the golden age of capitalism in the U.S. and Western Europe, the second third of the $20^{\text {th }}$ century, is due to the confluence of an economic theory that had a correct disease diagnosis, coupled with an economic practice that had tried to manage (even that in a very limited extent) ${ }^{9}$ the remedies proposed by that theory, by the actions from the government that played a role as an agent capable of assuming the task (institutionally and financially speaking) of applying these remedies. This Minsky Big Government defense is deeply rooted in his most large view that economic policy is not something cold and detached from the world, locked in the ivory towers of academic institutions and discussions. Rather, "[E]conomic policy must reflect an ideological vision, it must be inspired by the ideals of a good society" (Minsky, 2008 [1986], p. 10). And to him, in a good society

Social justice and individual liberty demand interventions to create an economy of opportunity in which everyone, except the severely handicapped, earns his or her way through the exchange of income for work. Full employment is a social as well an economic good. (Minsky, 2008 [1986], p. 7, italics added)

Given the systemic instability of the capitalist economy, the Government must act just like an economic stabilizer. Minsky analyses with greater accuracy the episodes of recession of the 1960s, 1970s and early 1980s, besides his particular periodization of the $20^{\text {th }}$ century, to demonstrate such proposition, mainly in his book Stabilizing an Unstable Economy (Minsky, 1986). In this task, he notes that

\footnotetext{
${ }^{9}$ It is a consensus among Post-Keynesians that the policies implemented under the generic term Keynesianism did not followed the Keynesian theoretical scope, in fact. These policies ignored the fundamental new aspects and possibilities highlighted by Keynes in his seminal writings (Keynes, 1936 and 1937), and resulted in a mix of orthodox policy recommendations with application of fiscal and monetary policy instruments in order to obtain a fine adjustment of aggregate demand. See Cardim de Carvalho (1992), Davidson (1978 and 1994), and Minsky (1975).
} 
the U.S. economy's performance on these recessions was saved from further depletion by the existence of countercyclical firepower within the Fed, playing as lender of last resort to the financial system, and also in the Government, playing as an agent capable of maintaining the rate of profits in a more stable path. Thus, beyond this, the Government was also able to reverse more quickly the descending phases of the cycle. In addressing the recession by expanding the deficit, the Government not only keeps the profits of the capitalists, but also prevents the major devaluation of financial assets that can generate the process of deflation of debts that are a key element of the FIH. As Minsky argues: the crucial role of the Fed and Big Government in the rapid U.S. economic recovery from the 1974-75 and 1981-82 is clear and sound: in these two periods, despite the recession, the rate of profit did not show a significant reduction, confirming the main thesis. ${ }^{10}$

But one can inquire why, in Minsky's view, the Government has become a so major economic player in the post-war period, since it evolves from the "small Government" of the 1920's? This results from the fact that, as put by Minsky, one needs to understand that the Government spending can be divided into four parts: 1) the Government production (postal services, police, the law, the army) as well as the jobs created for these purposes, 2) the Government contracts (by which Government buys what it needs, like when it buys military equipment or contract the construction of a road), 3) the transfer system (pensions, healthcare, unemployment insurance, social programs) and 4) the Government debt (interests on debt). It follows that, to see how the Government actions are able to avoid a deeper economic debacle, it is necessary to understand how the impact of deficits on the economy acts.

In Minsky perspective, Government deficits results in three clearly identifiable effects: 1) the income and employment effect, which arises from the actions of the Government demanding goods, services and employing its own workforce, 2) the budget effect, which operates through sectorial surpluses or deficits generated by the Government in different agents as it acts in the economy, and finally, 3) the portfolio effect, which exists because the financial instruments available to the Government to finance its deficits and surpluses have an asset valuation counterpart in other agents portfolios. Minsky states that the first effect is the most familiar one, which is usually investigated in economic models of determination of product or income. The second and third effects, however, are less clear and tend to be often ignored, despite its great importance to understanding the Government power in the economic sphere, given the sophistication of the relationships between the various actors in the capitalist economy. Minsky notes that Kalecki had a pioneering role in investigating the second effect, while the third effect is the object of investigation of those who lingered about the possibility of financial instability. And, finally, there are the cumulative effects drove by - in the U.S. Government case - the huge military budget and transfers payment, as he notes:

\footnotetext{
10 "[...] Big government stabilizes not only the employment and income but also business cash flows (profits) and as result asset value” (Minsky, 2008 [1986], p. 17).
} 
In recent years neither Government employment nor Government contracts, aside from the military, have made Government bigger in terms of this aggregate demand, financial flows, and portfolio effects. The Government is bigger now mainly because military spending, transfer-payment schemes, and the costs of servicing the national debt have grown. Transfer-payment schemes in particular have become so large a part of Government since World War II that the cyclical impact of Government spending is now largely determined by their impact. (Minsky, 2008 [1986], p. 22)

The Government became so great in the second half of the $20^{\text {th }}$ century in the pursue of the concern that it could provide the economy with a countercyclical stabilization system, fully capable of preventing the recurrence of a major crisis like the 1930s one. The Rooseveltian New Deal established a social protection network against unemployment and extreme poverty, and benefited from the favorable economic situation after the war - a post-crisis complete debt deflation, and a favorable situation in terms of increased demand, in addition to the massive possession of federal securities in public hands to finance the military mobilization. With this economic environment, there was an opportunity to get stronger and gain muscle, to cope with the recessionary cyclical reversals. In the 1929 crisis, the Government could not sustain the level of private investment that could prevent depression. But after the expansion of Government, in particular, after the improvement of its economic performance, it could put into action these three already mentioned effects of their deficits as tools for economic growth and to fight recessions. Minsky had no doubt about the capacity the Government has to end recessions, even the more acute ones, handling its fiscal instruments, in particular, the public deficits. ${ }^{11}$ The main thesis being proven, however, it remains an issue to investigate what are, in Minsky's view, the side effects these actions can produce.

If the Government supports incurring in increasing deficits when the economy is going down - as in a recession - it is right to advocate that is also part of its stabilizing role incurring into surpluses when the economy is doing well. It is only by the means of this balance that the Government can maintain a sustainable fiscal position. If, however, in the expansion phase, the Government does not make budget surpluses, it may weaken his budgetary position, leading it throughout ineffective fiscal policy in the sense of finding limitations to expand the deficit in recessions. In Minsky's perspective, the Government may face serious problems in refinancing its debts if he fails in showing it possess the ability to generate cash flows (tax income) enough to meet its payments commitments. As Minsky states:

\footnotetext{
11 "Big Government, with its potential for automatic massive deficits, puts a high floor under an economy's potential downward spiral” (Minsky, 2008 [1986], p. 36).
} 
A Government can run a deficit during a recession without suffering a deterioration of its creditworthiness if there is a tax and spending regime in place that would yield a favorable cash flow (a surplus) under reasonable and attainable circumstances.

There is nothing special about Government debt, and a flight from Government debt can occur. For a foreign-held debt such a flight will lead to a deterioration of the currency on exchanges; for a domestic debt the flight can lead to inflation and a need to pay even higher interest rate to have de debt held.

Incidentally, if the central bank - the Federal Reserve - monetizes Government debts in order to maintain its nominal price in the face of a deteriorating willingness to hold such debt, then there can be a run from the Federal Reserve as well as from commercial bank liabilities. Just as a private business debts have to be validated by profits, as bank liabilities by receipts from assets, as a foreign debt by an export surplus, so Government debt has to be validated by an excess of tax receipts over current expenditures. (Minsky, 2008 [1986], pp. 336-337, italics added).

In the United States, which is, in particular, the case of the minskian reasoning, the analysis of the Big Government side effects shows it had been possible to trigger a biased inflation process in the 1970s, not because of the Government itself being something like the so invocated "structurally inefficient" entity of the orthodox discourse, but instead by the kind of Big Government that emerged in the U.S. after the 1960s. First of all, that Big Government was a Government with a sky rocketing large military spending, measured as a proportion of the GNP, which is, in the U.S. particular case, linked with the context of the Cold War and the continuing involvement of the country in several minors military conflicts around world. Secondly, it is rooted in the 'establishment' acceptance of an orthodox view of the overall economic policy, designed to pursue low inflation through the handling of unemployment rates as the only significant adjustment variable (which is to say: by monitoring and fine tuning of a supposed non-accelerationist natural rate of unemployment). This resulted in the expansion of unemployment insurance spending in economic downturns, which have gained momentum, leading to a huge impact in the public deficit. The budget deficit, which used to be over increased in recessions, was not managed to produce surpluses during the subsequent expansions. This transfer system (growing unemployment insurance costs and military demobilization spending, like war pensions to veterans) have created an extremely rigid structure of spending transfers. This structure allowed the maintenance of income levels that had impacted the demand, without increasing the amount of the overall product: the beneficiaries of these programs were entitled a portion of the product for which they did not collaborate in a productive manner. As a consequence of this, the process degenerated into an inflationary spiral. The transfer system became a gigantic problem for the management of Big Government because, despite of the increasing disposable 
income impacts on demand side, it creates an inflationary bias in the economy, originating from the demand itself:

The existence of a large, increasing proportion of disposable income that is independent of employment or of the profitability of business is beneficial, for it sustains demand and thus prevents a very deep and sustained fall of the economy during a recession. On the other hand, the existence of such programs, combined with a tendency to expand their scope when the economy is in recession, is harmful, for they impart an inflationary bias to the economy. (Minsky, 2008 [1986], p. 29)

This inflationary bias, resulting from this demand inflow (benefited by the transfer programs which is not balanced by increasing the production), emerges from the fact that, as Minsky points out, such kind of transfers induces the economy to an erosion of labor force participation in the product, but not in its consumption. As demand grows, because the personal income is being sustained, there is no correspondence in the growth of the economy supply. Minsky states that these programs provide a wage floor that acts as a barrier to expanding the participation of the workforce in the product:

Transfer payments, which provide income without work, set floors to money wage rates. Each improvement in transfer-payment schemes has the effect of raising the price at which some people will enter the labor market. The effective productive capacity of the economy is eroded by decreasing labor force participation when price-deflated transfer-payment schemes are improved, especially if, as is our practice, eligibility depends on being either unemployed or out of the labor force. (Minsky, 2008 [1986], p. 29)

In the Minsky's alternative policy prescription, the Government role should not be to stimulate this "income taken for granted" policies, as there is such a thing like "protected exit of the workforce". Government must, instead, stimulate the workforce expansion, e. g., by including younger and older people in a proper way into the workforce, in order to expand the consumption at the same time that the product is also expanding, and the weight of transfers on the public deficit is receding. Taking up a theme which is of special interest to him, which is the question that income must come from work for all these people who are able to perform some sort of work, Minsky resumes their old discussions in full employment policies, and suggests an economic reform program in which the Big Government performs a crucial task in becoming the economy employer of last resort. His proposed agenda will be outlined briefly in the next section of this article. 


\section{A REFORM AGENDA FOR CAPITALISM}

The primary aim is a humane economy as a first
step toward a humane society. (Hyman Minsky,
Stabilizing an Unstable Economy, p. 326)

Minsky analysis is complete with a reform agenda that, coherently rooted on his FIH, proposed more than a simple change in orientation, thus limited in scope to a specific type of economic policy (fiscal or monetary) as proposed by the mainstream: the kind of reform proposed by Minsky has much broader scope. Minsky's heterodox apologetics is about a systemic nature reform. As he argues, a period of prosperity and stability of capitalism as were the 20 years after World War II are not the standard of this system, but the exception. In capitalism, investments, profits and capital assets are all interconnected dynamically and interact in a synchronic way that endogenously produces instabilities. In his words:

The conclusion of the analytical arguments is that turbulence - especially financial instability - is normal in a capitalist economy; the tranquil era between 1946 and 1966 was an anomaly. Furthermore, the inherent instability of capitalism is due to the way profits depend upon investment, the validation of business debts depends upon profits, and investment depends upon the availability of external finance. But the availability of financing presupposes that prior debts and the prices that were paid for capital assets are being validated by profits. Capitalism is unstable because it is a financial and accumulating system with yesterdays, todays and tomorrows. (Minsky, 2008 [1986], p. 327, italics added)

Thus, Minsky proposes that there is a crucial role for the active economic policy intervention in the economic sphere. The intervention aims to address the destabilizing tendencies of the market system, when it is left to its own, what he called, years later, the "anti-laissez-faire theorem":

The Anti-Laissez theorem is that 'in a world where the internal dynamics imply instability, a semblance of stability can be achieved or sustained by introducing conventions, constraints and interventions into the environment. The conventions imply that variables take on values other than those which market forces would have generated: the constraints, and interventions impose new initial conditions or affect parameters so that individual and market behavior change. (Minsky \& Ferri, 1991, pp. 20-21)

In fact, this theorem stems from his view that the market solution must come downstream of the institutional solution. ${ }^{12}$ The Minskyan reform agenda starts

12 "A program of reform needs to come to grips with the strengths and limitations of market mechanisms. 
with this perspective: it is clearly an interventionist one, strongly anchored in a broader institutionalist vision of the real functioning of the economic system. It is therefore a major agenda, because its scale is broader, a systemic scale, in fact, although that in the specific case in which he proposed this agenda (in the middle of the 1980s), Minsky takes the American situation as a starting point. As pointed out by Papadimitriou and Wray (2008, p. xxv), Minsky reformist agenda, as outlined in the Stabilizing..., is directed to four main areas: 1 ) the Government (its size, spending and tax structure); 2) the full employment strategy (the Government as employer of last resort); 3) the financial reform (financial and banking regulation), and 4) the market power of corporations. The common element in this reform agenda is that it favors capitalism with a low investment and high consumption, which maintains full employment (real full employment) and is based on small organizations. In the present work, we will emphasize only the proposals for the first two points, which concern us more closely.

\section{A proposal of Big Government agenda}

Economic policy only proposes, it is the economy that deposes. (Minsky \& Papadimitriou, 1994, p. 2)

Minsky is an advocate of Big Government, but not a giant one like that who is more closely criticized by him: the U.S. Government in the decades of 1970-1980. There is no doubt about the strategic importance of the Government as the main stabilizer of the economy, but there are limitations to the size that such Government should wear:

Big Government is the most important reason why today's capitalism is better than the capitalism which gave us the Great Depression. [...]. If its tax and spending schemes are properly designed, Big Government can also be a barrier to inflation. However, the proposition that Big Government is necessary does not imply that Government need be as big as our present Government, or that today's structure of Government spending, taxes, and regulation is either necessary or desirable." (Minsky, 2008[1986], p. 330).

If this is the fundamental reticence, it remains to establish how big it should be, then, the Government. In Minsky proposal, the size of Government should be equal or larger than to the magnitude of the investment, taken in terms of a propor-

\footnotetext{
Decentralized markets are fine social devices for taking care of the particular outputs and prices of an economy, but they are imperfect devices for assuring stability and guaranteeing efficiency where large expensive capital assets are used in production. [...] Once we achieve an institutional structure in which upward explosions from full employment are constrained even as profits are stabilized, then the details of the economy can be left to market processes" (Minsky, 2008 [1986], p. 329).
} 
tion of the product, in instance to fill the gap of investments in a downturn. In his words:

Big Government must be big enough to ensure that swings in private investment lead to sufficient offsetting swings in the Government's deficit so that profits are stabilized. This means that Government must be of the same order of magnitude as or larger than investment. (Minsky, 2008[1986], p. 330, italics added)

In numerical terms, this translates, as he proposes for the U.S., in a Government whose spending has a range from $16 \%$ to $20 \%$ of the GDP, considering the U.S. product in prosperity times. With a level of spending of this magnitude, based on data for the U.S. economy, he argues that it will be possible to defend the economy from a catastrophic decline in investments and profits. Extrapolating this principle to other economies than the U.S., Minsky thesis is that the Government should be able to spend as much as the normal level of investment in the country, considering normal growth times. By this proposal, the Government spending is like an insurance contract against an economic downturn, whose "prize" is given by the magnitude of taxes (which, as we have already seen, must be within a range from $20 \%$ to $50 \%$ of product, in his proposal).

Defining the Government size, Minsky goes a step away on, in discussing the "what should Big Government do?" agenda. His answer begins with a critique of the excessive weight of military spending in the U.S. economy, and not only because of its immediate financial effects, but because this kind of spending is imposed as a constraint against the development of other economy, since "the military takes up so much of GNP that resource creation and humane and cultural uses of Big Government are severely restricted" (Minsky, 2008 [1986], p. 333). This is a quite undesirable situation, as, in minskian view, "Political and intellectual resources must be invested in the creation and maintenance of an effective Government apparatus because Big Government is here to stay if we are to avoid great depressions" (Idem, p. 334).

Minsky turns to the Keynes proposals - including his works written before the General Theory - to points out that the emphasis in public spending could be generating employment, financed through deficit, not in things like military spending, but in productive assets, instead, like the construction of infrastructure, which ultimately constitute assets for the country as a whole, improving the overall economic productivity. The problem with the Big Government, at the time Minsky is writing, is that the deficit has been directed to non-productive expenditure, in the opposite way of the recommendations and fundamental prescriptions of Keynes: there was too much transfers scheme to sustain that kind of "cradle to grave" security" Government (Minsky, ibidem). Thus, to Minsky, the fundamental point of the Government's agenda should be based on a fundamental institutional change, 
in a way to replace the gigantic system of transfers for the kind of spending that can create economy additional resources. ${ }^{13}$

In Minsky view, a real full employment policy constitutes the kind of spending that is the effective resources creator and driving force of the economy. And when Minsky is speaking about real full employment, such "full employment" is different from the concept of "full employment" which is derived from neoclassical synthesis and, later, by the New Consensus. In both schools, full employment means to maintain employment levels as high as possible, while accepting a percentage of people unemployed, at any time, in order to keep inflation under control while the product fluctuates within a narrow theoretical "potential output". In the opposite side, in Minsky proposals, the thesis that the solution to poverty is an unlimited jobs supply, which is granted in least instance by the Government itself, is one of the banners he championed even long before the formulating of the FIH final form. These ideas - in part derived from the personal life experience of Minsky, as he worked in the employment of last resort programs of the Roosevelt years - was presented in a chapter of a book published in 1965, discussing about the fight against poverty. That work was his first proposal for an economic policy explicitly focused on full employment as a social value, to be actively pursued by the Government:

A necessary ingredient of any war against poverty is a program of job creation; and it has never shown that a thorough program of job creation, taking people as they are, will not, by itself, eliminate a large part of the poverty that exists.

The war against poverty cannot be taken seriously as long as the Administration and the Congress tolerate a five per cent unemployment rate and frame monetary and fiscal policy with a target of eventually achieving a four percent unemployment rate. Only if there are more jobs than available workers over a broad spectrum of occupations and locations can we hope to make a dent on poverty by way of income from employment. (Minsky, 1965, p. 175)

This idea is what turns out to be, in Minsky perspective, the effective strategy to fight poverty. He calls it "Tight Full Employment Policy". Only by means of a change in the institutional vision and action in the Government economic policy is how an effective "war against poverty" can be successful:

The war against poverty must not depend solely, or even primarily, upon changing people, but it must be directed toward changing the system. However, the changes required are not those that traditional

\footnotetext{
13 "The overall policy perspective is to substitute resource-creating public spending for the multitude of transfer payments and entitlements that now make up a major part of nonmilitary spending” (Minsky, 2008 [1986], p. 334).
} 
radicals envisage. Rather they involve a commitment to the maintenance of tight full employment and the adjustment of institutions, so that the gains from full employment are not offset by undue inflation and the perpetuation of obsolete practices. (Minsky, 1965, p. 176, italics added)

He defines this policy as follows: "Tight full employment exists when over a broad cross section of occupations, industries, and locations, employers, at going wages and salaries, would prefer to employ more workers than they in fact do" (Minsky, 1965, p. 177). It is such a policy that he proposes as a fundamental part of the changing agenda for the Big Government of the late $20^{\text {th }}$ century. Based on figures from the U.S. economy in 1983, Minsky suggests a policy of employer of last resort that, by employing the unemployed actually eligible to unemployment insurance, as well as the young, the elderly, and housewives (among others) with availability to do part-time work (or even full time work), represents a cost of $1.25 \%$ of the proceeds of full employment GNP. Besides, a child care policy whose impact would be, at the time, an amount of $1.33 \%$ of the GNP, would be a tool to remove from poverty that families who have jobs but who remain poor because of its size (in number of children). In short, however, the fact is that Minsky argues that spending on transfers (that are sticky, growing and unproductive) must be redirected in a way in which Government create jobs to fight unemployment. Big Government is able to promote such kind of policy, as it figures out as the only economic agent that can have an infinitely elastic demand for labor, paid by a minimum wage whose value is set by Government itself. In doing so, the correct way to Big Government to be big is taking an employer of last resort program to eliminate unemployment, besides of promoting the training and professional updating of the unemployed, in order to increase their productivity, and establishing a floor for wages as a benchmark for the overall economy. In that way, the Government would be creating a policy similar to that of buffer stocks, applied to the employment level of the economy, acting with a distinctive stabilizing character. It promotes an economy based on high consumption, as the most significant part of household income is derived from labor income, and a lower level of investment.

\section{CONCLUSION}

Minsky has become a reference in these troubled times, in particular after the emergence of the Subprime Crisis in U.S. in 2007. Recursively, FIH, his main theoretical contribution, has been remembered as a powerful tool for analyzing the complex interface between the capitalist system and its financial dimension, nowadays even more gigantic than ever, and more ubiquitous too. The idea that there is a fundamental and endogenous weakness in the system, coming from the agents behavior in terms of unraveling their level of confidence in systemic stability is a very strong proposition that clear very deeply much of our understanding of our time capitalism. By assuming increasing risks each time the economy appears to 
walk swiftly toward more and more prosperity, eventually resulting in weakening of the liabilities structure, which comes to the canvas when a crisis starts, seems to explain perfectly the financial crises in the last decades of $20^{\text {th }}$ century, as the actual crisis too. Moreover, it helps to understand why, despite the frequency of the cycles of optimistic expansion to growing instability and then to debt deflations and crisis, none of the last downturns were as "It", the crisis - this entity about which Minsky paid so much respect and theoretical interest (in true, almost like a deference). Such kind of a cataclysmic event in the economic and social order, when the financial instability reaches the brink of the abyss and a Great Depression bursts have been circumvented by the Big Government and Big Bank actions, as they are the economic agents large enough to prevent the ground crumble beneath the feet of the other agents.

Minsky own research program was an attempt to understand how an event so cataclysmic is set up in the run of the economic cycle and what triggers the reverse of the trend, but beyond this, he want to understand how to prevent it, also, how to tame the system to prevent that "It" is repeated once more. In the present paper, we saw that in the Minskyan approach, following the Post-Keynesian tradition, the remedy to heal the economy must be managed by the agent large enough to face the monster (if it appears so). But in a more cautiously management of the economic system, the crucial role of this giant economic agent is to avoid creating the environment in which the monster manifests itself. This giant agent is the "Big Government", this another "entity" that, although in its institutional role it is so important to Minsky theory, in terms of his theoretical contribution it has been relegated to the marginal background in most analyzes of Minsky work. In our view, the role of Big Government in Minsky view is of fundamental importance to prevent the construction of the environment in which a destructive crisis takes place - which is to say: without Big Government doing its job, "It" can (and will) happen. This is an important issue to discuss, especially in these days, when the 2007-2008 crises has been analyzed and, although there is crystal evidence against the kind of theory that has been the cornerstone of economic policy that drove us to this situation, there is an ideological defense of minimum Government being preached as a solution to it.

As we have been seeing in the last years since the 2008 turmoil, there is a discussion gaining momentum about the predictive power of an economic theory which founded itself by putting some unrealistic issues as the pillars of all economic system, and then recommending that the Government is unable to handle with real economic problems. Notwithstanding, was the Big Government that has had bailed out the financial system from a free fall into the abyss that it had digged to itself with imprudence, laxity, deregulation and some "serious" (and silly) economic theoretical background. And after the first shock, there is a second one, in the form of a discussion about the deficit expansions, which has been shaking both sides of North Atlantic. In the U.S. this debate is more ideological that theoretical, and has been changed in an total and nonsense concern about things like "fiscal cliff"; in the Eurozone, the austerity creed has degenerated into an almost new edi- 
tion of the Big Depression, with some countries showing unemployment rates soaring above $25 \%$ of the working force. Yet the policy discussion is about reducing the Government, and not fighting unemployment! There is some space for the application of Minskyan policies about unemployment, and for a re-regulation of financial system more prone to the kind of analysis with which Minsky has provided us, but the blindness of the autistic mainstream economic thought is resistant to the challenge of the real facts.

Minsky advocates an active role for the Government in terms of counter-cyclical policies, but not only through traditional means, like managing monetary and fiscal policy. Minsky was an advocate of a Government that would enjoy greater tax revenues, and promptly to act in order to achieve surpluses in times of economic growth, with the objective of to be able to cope with the fall of the level of investment in slump times. The Government is, for him, the more effective automatic stabilizer against the vagaries inherent to the system. At the same time, the Government should be a promoter of a soundness real full employment policy. Minsky argues that only by creating jobs in a quantity enough to make labor a rare commodity in the market, the Government struggle against fundamental capitalism problems such as poverty and extreme inequality could be effectively treated. That is the picture of our world nowadays, and this is the space where Minsky's proposals should have being implemented.

It is possible to say, therefore, that the Minsky contribution goes far beyond the financial instability hypothesis, which is his most prominent contribution. There is much more about Minsky than only FIH: there is an attempt to make economics a science with more adherence to the real world, in line with the Post-Keynesian tradition, and there is a struggle against any ideas that, like the deregulating of the financial system, or diminishing the Government size, or preaching about an axiomatic market efficiency, promotes more instability able to generate great depressions in its trail. Minsky died in 1996 with a long list of original contributions to economic science, with a defense of creative policies that could be helping to correct the trajectory which evolved by the means of "irrational exuberance" and extreme laxity in financial regulation, and by the constant fight against the active Government role, letting "It" - or, at least, something very like it - visit us again, as happened in 2008. It was not for lack of notice. As remind us some of those who worked with Minsky, were he alive today to witness the unfolding of the 2007-2008 crisis and its current implications in the U.S. and the Eurozone, he would be saying - with the propriety and the lucidity of a person who saw the weakness before everyone else - "I told you so..."

\section{REFERENCES}

Cardim de Carvalho, Fernando J. Mr. Keynes and the Post-Keynesians: principles of macroeconomics for a monetary production economy. Aldershot (UK): Edgar Elgar Publishing, 1992.

Cardim de Carvalho, Fernando J. Economic Policies for Monetary Economies: Keynes's economic 
policy proposals for an unemployment-free economy. Revista de Economia Política, Vol. 17, n. 4 (68), Out-Nov, 1997, pp. 31-51.

Cardim de Carvalho, Fernando J. Keynes and the reform of the capitalist social order. Journal of PostKeynesian Economics, Vol. 31, n. 2 (131(, Winter, 2008, pp. 191-211.

Cardim de Carvalho,Fernando J. Systemic Crisis, Systemic Risk and the Financial Instability Hypothesis. In: E. Hein, T. Niechoj and E. Stockhammer (Eds.), Macroeconomic Policies on Shaky Foundations. Berlin: Metropolis-Verlag, 2009, pp. 261-82.

Cassidy, John. The Minsky Moment. The New Yorker, February 4, 2008. http://www.newyorker.com/ talk/comment/2008/02/04/080204taco_talk_cassidy.

Davidson, Paul. Money and the real world. $2^{\text {nd }}$ ed. London: MacMillan, 1978.

Davidson, Paul. Post Keynesian macroeconomic theory: a foundation for successful economic policies for the twenty-first century. Cambridge: Edward Elgar, 1994.

Erturk, Korkut. On the Minskyan Business Cycle. Annandale-on-Hudson, NY: The Levy Economics Institute of Bard College, Working Paper n. 474, August, 2006.

Ferri, Piero. Growth Cycles and the Financial Instability Hypothesis (FIH). In: Papadimitriou, Dimitri B.; Wray, L. Randall (Eds.). The Elgar Companion to Hyman Minsky. Cheltenham (UK): Edgar Elgar, 2010, pp. 206-21.

Fisher, Irving. The Debt Deflation Theory of Great Depressions. Econometrica, (1), 1993, pp. 337-57.

Kalecki, Michal. The Determinants of Profits. In: Kalecki, M. Selected Essays on the Dynamics of the Capitalist Economy. Cambridge: Cambridge University Press, 1971.

Keynes, John Maynard. The general theory of employment, interest and money. The Collected Writings of John Maynard Keynes, Vol VII. Cambridge: Macmillan/Cambridge University Press, 1973.

Keynes, John Maynard. The general theory of employment. The Quarterly Journal of Economics, Vol. 51, n. 2, Feb. 1937, pp. 209-23.

Kregel, Jan. Minsky's Cushions of Safety: systemic risk and the crisis in the U.S. subprime mortage market. Public Policy Brief, Highligts, n ${ }^{\circ}$ 93A. Annandale-on-Hudson, NY: The Levy Economics Institute of Bard College, 2008.

Kregel, Jan. Fiscal Responsibility: What exactly does it means? Annandale-on-Hudson, NY: The Levy Economics Institute of Bard College, Working Paper n. 602, June, 2010.

Lahart, Justin. In Time of Tumult, Obscure Economist Gains Currency. The Wall Street Journal, August, 18 (2007). http://online.wsj.com/public/article/SB118736585456901047.html.

Minsky, Hyman P. The Role of Employment Policy. In M.S. Gordon (Ed.). Poverty in America. San Francisco: Chandler Publishing Company, 1965.

Minsky, Hyman P. John Maynard Keynes. New York: McGraw-Hill, 2008 (1975).

Minsky, Hyman P. Money, Financial Markets and the Coherence of a Market Economy. Journal of Post-Keynesian Economics, Vol. III, n. 1, (Fall 1980), pp. 21-31.

Minsky, Hyman P. Can "It" Happen Again? Essays on Instability and Finance. Armonk/New York: M.E. Sharpe, 2008 (1982).

Minsky, Hyman P. (1985). Beginnings. Banca Nazionale Del Lavoro Quarterly Review, n. 154, Setembro, 1985.

Minsky, Hyman P. Stabilizing an Unstable Economy. $2^{\text {nd }}$ ed. New York: McGraw-Hill, 2008 (1986).

Minsky, Hyman P. Is 'Keynesian Policy” Still Viable? (Draft and Transcription). Hyman P Minsky Archive, Paper n. 11 (1994:1). http://digitalcommons.bard.edu/hm_archive/11.

Minsky, Hyman P. Failed and Successful Capitalisms: Lessons From the Twentieth Century. Hyman P. Minsky Archive, Paper n. 47. (1994:2). http://digitalcommons.bard.edu/hm_archive/47

Minsky, Hyman P. The Debt Deflation Theory of Great Depressions. Hyman P. Minsky Archive, Paper n. 159 (1994:3). http://digitalcommons.bard.edu/hm_archive/159.

Minsky, Hyman P. Financial Factors in the Economics of Capitalism. Hyman P. Minsky Archive, Paper n. 64. (1995). http://digitalcommons.bard.edu/hm_archive/64.

Minsky, Hyman P.; Ferri, Piero. Market Processes and Thwarting Systems. Annandale-on-Hudson, NY: The Levy Economics Institute of Bard College, Working Paper n. 64, November, 1991. 
Minsky, Hyman P.; Papadimitriou, Dimitri B. Why Not Give Full Employment a Chance. Hyman P. Minsky Archive, Paper n. 173 (1994). http://digitalcommons.bard.edu/hm_archive/173.

Papadimitriou, Dimitri B.; Wray, L. Randall. Minsky's Stabilizing an Unstable Economy: two decades later. In: Minsky, Hyman P. Stabilizing an Unstable Economy. ${ }^{\text {nd }}$ ed. New York: McGraw-Hill, 2008.

Papadimitriou, Dimitri B.; Wray, L. Randall. Introduction: Minsky on money, banking and finance. In: Papadimitriou, Dimitri B.; Wray, L. Randall (Eds.). The Elgar Companion to Hyman Minsky. Cheltenham (UK): Edgar Elgar, (2010), pp. 1-30.

Sinapi, Christine. Institutional Prerequisites of Financial Fragility within Minsky's Financial Instability Hypothesis: A Proposal in Terms of "Institutional Fragility". Annandale-on-Hudson, NY: The Levy Economics Institute of Bard College, Working Paper n. 674, July, 2011.

Toporowski, Jan. Methodology and Microeconomics in the Early Work of Hyman P. Minsky. Annandale-on-Hudson, NY: The Levy Economics Institute of Bard College, Working Paper n. 480, November, 2006.

Whalen, Charles. The U.S. Credit Crunch of 2007: A Minsky Moment. Public Policy Brief 92. Annandale-on-Hudson, NY: The Levy Institute of Bard College, 2007.

Wray, L. Randall. The Dismal State of Macroeconomics and the Opportunity for a New Beginning. Annandale-on-Hudson, NY: The Levy Economics Institute of Bard College, Working Paper n. 652, March, 2011:1.

Wray, L. Randall. Minsky Crisis. Annandale-on-Hudson, NY: The Levy Economics Institute of Bard College, Working Paper n. 659, March, 2011:2. 